\title{
Some new types multivalued $F$-contractions on quasi metric spaces and their fixed points
}

\section{Hatice Aslan Hançer, Murat Olgun and Ishak Altun}

\begin{abstract}
.
In this paper we present two new results for the existence of fixed points of multivalued mappings with closed values on quasi metric space. First we introduce the multivalued $F_{d}$-contraction on quasi metric space $(X, d)$ and give a fixed point result related to this concept. Then taking into account the $Q$-function on a quasi metric space, we establish a $Q$-function version of this concept as multivalued $F_{q}$-contraction and hence we present a fixed point result to see the effect of $Q$-function to existence of fixed point of multivalued mappings on quasi metric space.
\end{abstract}

Acknowledgement. The authors are grateful to the referees because their suggestions contributed to improve the paper.

\section{REFERENCES}

[1] Alemany, E. and Romaguera, S., On half-completion and bicompletion of quasi-metric spaces, Comment. Math. Univ. Carolin, 37 (1996), No. 4, 749-756

[2] Al-Homidan, S., Ansari, Q. H. and Yao, J. C., Some generalizations of Ekeland-type variational principle with applications to equilibrium problems and fixed point theory, Nonlinear Anal., 69 (2008), No. 1, 126-139

[3] Alghamdi, M. A., Berinde, V. and Shahzad, N., Fixed points of multivalued nonself almost contractions, J. Appl. Math., 2013, Article ID 621614, 6 pp.

[4] Altun, I., Olgun, M. and Minak, G., Classification of completeness of quasi metric space and some new fixed point results, Nonlinear Funct. Anal. Appl., 22 (2017), No. 2, 371-384

[5] Altun, I. and Dağ, H., Nonlinear proximinal multivalued contractions on quasi-metric spaces, J. Fixed Point Theory Appl., 19 (2017), 2449-2460

[6] Altun, I., Durmaz, G., Minak, G. and Romaguera, S., Multivalued almost F-contractions on complete metric spaces, Filomat, 30 (2016), No. 2, 441-448

[7] Altun, I., Mınak, G. and Dağ, H., Multivalued F-contractions on complete metric space, J. Nonlinear Convex Anal., 16 (2015), No. 4, 659-666

[8] Altun, I., Olgun, M. and Minak, G., A new approach to the Assad-Kirk fixed point theorem, J. Fixed Point Theory Appl., 18 (2016), No. 1, 201-212

[9] Altun, I., Olgun, M. and Minak, G., On a new class of multivalued weakly Picard operators on complete metric spaces, Taiwanese J. Math., 19 (2015), No. 3, 659-672

[10] Berinde, M. and Berinde, V., On a general class of multi-valued weakly Picard mappings, J. Math. Anal. Appl., 326 (2007), No. 2, 772-782

[11] Cobzaş, S., Completeness in quasi-metric spaces and Ekeland variational principle, Topol. Appl., 158 (2011), 1073-1084

[12] Cobzaş, S., Functional analysis in asymmetric normed spaces, Springer, Basel, 2013

[13] Cosentino, M. and Vetro, P., Fixed point results for F-contractive mappings of Hardy-Rogers-type, Filomat 28 (2014), No. 4, 715-722

Received: 14.02.2018; In revised form: 03.12.2018; Accepted: 10.12.2018

2010 Mathematics Subject Classification. 54H25, 47H10.

Key words and phrases. Quasi metric space, left $K$-Cauchy sequence, left $K$-completeness, fixed point, multivalued mapping, Q-function.

Corresponding author: Ishak Altun; ishakaltun@yahoo.com 
[14] Dağ, H., Mınak, G. and Altun, I., Some fixed point results for multivalued F-contractions on quasi metric spaces, RACSAM, 111 (2017), No. 1, 177-187

[15] Feng, Y. and Liu, S., Fixed point theorems for multi-valued contractive mappings and multi-valued Caristi type mappings, J. Math. Anal. Appl., 317 (2006), 103-112

[16] Kelly, J. C., Bitopological spaces, Proc. London Math. Soc., 13 (1963), 71-89

[17] Künzi, H. P. A., Nonsymmetric distances and their associated topologies: about the origins of basic ideas in the area of asymmetric topology, In: Aull, CE, Lowen, R (eds.) Handbook of the History of General Topology, vol. 3, pp. 853-968, Kluwer Academic, Dordrecht 2001

[18] Künzi, H. P. A. and Vajner, V., Weighted quasi-metrics, Ann. New York Acad. Sci., 728 (1994), 64-67

[19] Latif, A. and Al-Mezel, S. A., Fixed point results in quasimetric spaces, Fixed Point Theory Appl., 2011, Article ID 178306, 8 pp.

[20] Marín, J., Romaguera, S. and Tirado, P., Generalized contractive set-valued maps on complete preordered quasimetric spaces, J. Funct. Spaces Appl., 2013, Article. ID 269246, 6 pp.

[21] Marín, J., Romaguera, S. and Tirado, P., Q-functions on quasi-metric spaces and fixed points for multivalued maps, Fixed Point Theory Appl., 2011, Article ID 603861, 10 pp.

[22] Minak, G., Olgun, M. and Altun, I., A new approach to fixed point theorems for multivalued contractive maps, Carpathian J. Math., 31 (2015), No. 2, 241-248

[23] Reilly, I. L., Subrahmanyam, P. V. and Vamanamurthy, M. K., Cauchy sequences in quasi- pseudo-metric spaces, Monatsh. Math., 93 (1982), 127-140

[24] Sgrio, M. and Vetro, C., Multi-valued F-contractions and the solution of certain functional and integral equations, Filomat, 27 (2013), No. 7, 1259-1268

[25] Udo-utun, X., On inclusion of F-contractions in $(\delta, k)$-weak contractions, Fixed Point Theory Appl., 2014, 2014:65, 6 pp.

[26] Wardowski, D., Fixed points of a new type of contractive mappings in complete metric spaces, Fixed Point Theory Appl., 2012, 2012:94, 6 pp.

\section{DEPARTMENT OF MATHEMATICS}

FACULTY OF SCIENCE AND ARTS

KIRIKKALE UNIVERSITY

71450 YAHSIHAN, KIRIKKALE, TURKEY

Email address: haticeaslanhancer@gmail.com, ishakaltun@yahoo.com

DEPARTMENT OF MATHEMATiCS

FACULTY OF SCIENCE

ANKARA UNIVERSITY

06100, TANDOGAN, ANKARA, TURKEY

Email address: olgun@ankara.edu.tr 